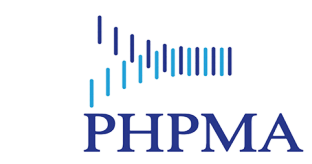

Published by Department of Public Health and Preventive

Medicine, Faculty of Medicine, Udayana University

\section{Community participation in the utilization of village fund for stunting prevention: Case study in two villages in Gianyar District}

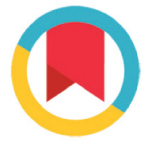

CrossMark

\author{
Made Ayu Diah Prabasari, ${ }^{1 *}$ Dinar Saurmauli Lubis, ${ }^{2}$ Ni Ketut Sutiari ${ }^{2}$
}

${ }^{1}$ Public Health Postgraduate Program, Faculty of Medicine, Udayana University ${ }^{2}$ Department of Public Health and Preventive Medicine, Faculty of Medicine, Udayana University
*Correspondence to:

Made Ayu Diah Prabasari;

Public Health Postgraduate Program,

Faculty of Medicine, Udayana University; ayupraba2326@gmail.com

\section{ABSTRACT}

Background and purpose: The Indonesian government has set a target to reduce stunting prevalence from $27.7 \%$ in 2019 to $14 \%$ in 2024. There are 10 villages in Gianyar District have been selected as stunting loci since 2018, however, the percentages of the village fund utilized for health and nutrition were low. This research aims to identify the level of community participation in the utilization of village fund for stunting prevention in two stunting loci villages in Gianyar.

Methods: This was a qualitative study using a multiple case study approach conducted in two stunting loci villages in Gianyar, Bali. Data collection was conducted from May to June 2020 through in-depth interview with 12 key informants. Thematic qualitative analysis was done using the ladder of participation concept with Arnsteinand political approach by Carpentier which involves several key concepts such as process, field, actor, decision making moment and power.

Results: The level of community participation in the village fund utilization for stunting prevention was still in the of pseudo participation - Placation level. The majority of proposals or recommendation for stunting prevention program came from cadres of community health post, health care workers and the village assistants. Final decision making in the planning stage was largely depending on the village government. The community plays the role as program recipient. Several challenges for optimal utilization of village fund for stunting prevention were geographical condition, paternalistic leadership as well as the lack of understanding and capacity of key actors.

Conclusion: The community participation in utilization of the village fund for stunting program in the two villages was in the vague participation level. The village government should provide more rooms to empower the community in order to increase their participation level.

Keywords: community participation, stunting locus, village fund

Cite This Article: Prabasari, M.A.D., Lubis, D.S., Sutiari, N.K. 2021. Community participation in the utilization of village fund for stunting prevention: Case study in two villages in Gianyar District. Public Health and Preventive Medicine Archive 9(2): 9199. DOI: 10.15562/phpma.v9i2.293

\section{INTRODUCTION}

Stunting in children under five years old is a global problem. In 2018, it is estimated that $21.9 \%$ of children under five are stunted worldwide. ${ }^{1}$ In Indonesia, the prevalence of stunting in under five children in 2019 was $27.7 \%{ }^{2}$ Stunting in this demography can lead to various adverse effects in the future, including impeded physical growth, psychological and emotional development problems, cognitive disorders and low performance in school. In addition, it can also cause disorders of fat metabolism that increases the risk of obesity. Various physical and psychological delays as well as the impeded cognitive development can lead to lower social status and income. . $^{3-8}$

Stunting reduction is a priority for Indonesian current national development plan. The government is targeting a reduction in the prevalence of child stunting by half in 5 years, to $14 \%$ by 2024. ${ }^{2}$ In order to achieve that target, the government has gradually mapped out and identified districts and villages where stunting is prevalent in Indonesia and established them as stunting loci. Gianyar District in Bali Province is one of the stunting loci. The ten villages in Gianyar District which selected as stunting loci were Siangan, Sanding, Manukaya, More, Lodtunduh, Singekerta, Kedisan, Pupuan,
Taro and Bresela. ${ }^{9}$

The challenge that the government still faces is that stunting reduction policies and programs have not been properly translated into regional planning and budgeting. One of the performance indicators of the convergence of stunting prevention is the percentage of village fund utilization for priority nutrition intervention activities. ${ }^{9}$ Utilization of village funds for priority nutrition interventions can be assessed through the percentage of utilization of village funds for UKBM (community based health enterprises). The Ministry of Health through the Health Promotion and Community Empowerment program stipulates a minimum of $10 \%$ of village 
funds to be used for UKBM. ${ }^{10}$

Based on the data from the Health Promotion and Community Empowerment Program Gianyar District Health Office (DHO), the percentage of allocation and utilization of village funds for UKBM in Gianyar in 2018 was only $8.95 \%$. While, in 2019 the percentage of village funds utilization for $U K B M$ in Gianyar increased to $23.59 \%$. However, there was a gap between villages in allocating their village funds for UKBM in the stunting loci. The highest percentage of village fund allocated for UKBM was found in Sanding Village (72.18\%) and the lowest was in Lodtunduh Village (16.11\%). ${ }^{11}$

The Village Minister Regulation has established stunting management through specific nutrition and sensitive nutrition activities as one of the priorities in the use of village funds in 2019 and 2020.12-13 In the process of setting priorities for the use of village funds, several stages need to be carried out including village meetings, preparation of RKPDes (The Village Work Plan), determination of priority plans for the use of village funds, drafting of APBDes (The Village Budget Plan) and review of APBDes. The Village Minister Regulation also states the principles that must be used as the basis for determining priorities for the use of village funds, including village authority, priority for village needs, participation, justice, self-management, focus, and based on village resources. ${ }^{12}$

Community participation is the key to optimal utilization of village funds according to community needs. Participation is important because the people are entitled to the right to contribute for the decisions that affect their lives. Village governments should pay attention to inputs from the community members because community participation can help allocate resources more effectively and efficiently, enable communities to be more responsive to needs, help develop community competencies, skills and capacities, as well as offer new opportunities for creative and innovative thinking. ${ }^{14}$

Previous studies have shown that community participation is still lacking in the decision-making regarding utilization of village funds for village development.
The village government is seen as not fully recognize the community aspirations and not all communities are involved in decision making process. ${ }^{15}$ Community participation is seen as merely a formality, administrative order and centered on the village apparatus. ${ }^{16}$ The community considers the village Musrenbang (people's meeting for planning and development) activities to be merely a formality. ${ }^{17}$ The trend of health-related program development carried mostly centered around physical development compared to health promotion activities. In addition, the health workers in the village as health development actors are facing difficulties in identifying the basic needs and problems, mobilizing resources and planning activities. ${ }^{18}$

Thus, the purpose of this study was to identify the level of community participation in village funds utilization for stunting prevention in stunting loci in Gianyar District by taking two villages, Sanding as the village with the highest allocation and Lodtunduh with the lowest, for case studies.

\section{METHODS}

This was a qualitative study with a multiple case study approach in two selected villages which were identified as stunting loci, namely Lodtunduh Village with the lowest percentage of village fund utilization for health in 2019 and Sanding Village with the highest percentage of utilization. The qualitative approach was chosen because the issue of participation is often difficult to define precisely or measure objectively because it is very subjective. The qualitative method allows researchers to understand more deeply about the obstacles and challenges in the use of village funds for stunting management in the stunting loci in Gianyar District.

Qualitative data collection was conducted through in-depth interviews. Informants were selected by purposive sampling, informants were those who considered as having a key role in the utilization of village funds for handling stunting, including the village government, community leaders, village health workers and village assistants. In the current situation of the COVID-19 pandemic there were several obstacles that researchers encountered in data collection so that only 8 informants could be interviewed face-to-face, while 4 others were interviewed by telephone.

Before conducted the interview, the researcher first explained the purpose and objectives of the study and asked the informants' consent to participate in the study. Informants who were willing to participate then signed the informed consent (face-to-face interview) or expressed consent verbally (telephone interview). In-depth interviews were conducted directly by the researcher with an interview guide. The interview stopped after all the questions in the interview guide had been asked and the information gathered deemed as sufficient by the researcher. The length of the interview varied for each informant, ranging from 15-60 minutes. Interview activities were recorded using a voice recorder application on the researcher's cellphone. The recordings were transcribed immediately after completion of the interview. Vague and questionable data after transcription were reconfirmed and clarified to the informants to obtain certainty and completeness.

Secondary data such as the village profile documents, RKPDes (The Village Work Plan) documents and APBDes (The Village Budget Plan) documents for Sanding and Lodtunduh Villages in 2019 and 2020 were also collected as complementary information. These documents were obtained at the village office and given directly by the in charge village apparatus.

Qualitative data analysis was carried out thematically by referring to Arnstein's Ladder of Participation (1969). ${ }^{19}$ This theory focuses attention on community participation and power relations. The Arnstein ladder of participation includes eight rungs which are further categorized into upper, middle, and lower levels of participation. The lower level, namely manipulation and therapy, represents the level of non-participation because the government holds the real power to avoid the participation of local community in decision making. The middle rung, namely informing, consultation and placation, describes the apparent level of participation that allows the community to 
know and give opinions about a program however it is not certain that their views will be considered in the decision-making process. The top rung is partnership, delegated power and citizen control. Real participation begins where negotiations between various stakeholders are included and the communities take part of the responsibility for decision making. At the level of delegated power and citizen control, people's views have been taken into account in the decision-making process and they are empowered to make decisions about development. ${ }^{19}$

In facilitating the thematic analysis, researchers also refer to Carpentier ${ }^{20}$ who developed an analytical model for participatory research with a political approach according to Arnstein's ladder of participation theory. Carpentier's model uses a series of key concepts namely process, field, actor, decision making moment and power.

This research was approved by the Ethical Committee of the Medical Faculty, Udayana University/Sanglah Hospital on May 14, 2020 with number: 1022/ UN14.2.2.VII.14/LT/2020.

\section{RESULTS}

Key informants' characteristics and summary of qualitative analysis

The characteristics of informants are presented in Table 1. The informants are the key figures in the utilization and allocation of village funds for stunting prevention.

Table 2 presents a summary of the results from the qualitative analysis. There were 6 themes and 17 sub-themes emerged from the analysis. The six themes were the participatory planning process, the actors involved, the leadership position of the actors, decision making process, the village context and the form of community participation.

\section{Participatory planning process}

Village funds are one of the sources of village income so that prioritizing the use of village funds should follow the village planning and budgeting process. ${ }^{12}$ The Lodtunduh and Sanding Village Governments have carried out these stages in the village fund planning process according to the government regulations.

Table 1. Key informants' characteristics

\begin{tabular}{cccccc} 
Code & $\begin{array}{c}\text { Role in the village } \\
\text { community }\end{array}$ & Gender & Age & Education & $\begin{array}{c}\text { Years } \\
\text { of } \\
\text { service }\end{array}$ \\
\hline LO_01 & Village government & M & 50 & Senior high school & 7 \\
LO_02 & Village government & M & 28 & Bachelor & 3 \\
LO_03 & Village government & M & 43 & Senior high school & 3 \\
LO_04 & Village opinion leader & M & 45 & Senior high school & 12 \\
LO_05 & Village assistant & M & 38 & Bachelor & 5 \\
LO_06 & Health care worker & F & 36 & 3 years diploma & 11 \\
LO_07 & Health care worker & F & 38 & Junior high school & 11 \\
SA_01 & Village government & M & 57 & Senior high school & 15 \\
SA_02 & Village government & M & 28 & Vocational High School & 3 \\
SA_03 & Village opinion leader & M & 50 & Bachelor & 23 \\
SA_04 & Health care worker & F & 40 & 3 years diploma & 14 \\
SA_05 & Health care worker & F & 33 & 3 years diploma & 9 \\
\hline
\end{tabular}

$\mathrm{M}=$ Male, $\mathrm{F}=$ Female

\section{Table 2. Summary of qualitative results analysis}

\begin{tabular}{lll}
\hline \multicolumn{2}{c}{ Sub Themes } & \multicolumn{1}{c}{ Themes } \\
\hline 1. & $\begin{array}{l}\text { Deliberations to determine strategic matters } \\
\text { 2. }\end{array}$ & Deliberations to identify public health problems \\
\hline 1. & Village government group & Involved actors \\
2. & Community group & \\
3. & External actors group & \\
\hline 1. & Inequality of power and position in the village level & Leadership position in the \\
2. & Gender inequality in the grassroot level & village \\
\hline 1. & Decide on strategic matters by consensus & Decision making process \\
2. & Develop a priority scale & \\
3. & Adjusting to the final budget allocation & \\
4. & Presence of a routine budget & Village context \\
\hline 1. & The village teritorial scope & \\
2. & Lack of understanding among actors & \\
3. & Low capacity of actors & \\
4. & Mandatory national program for the villages & \\
5. & Changing of village midwife & \\
6. & Paternalistic and responsive leadership style & Form of participations \\
\hline 1. & Passive participation &
\end{tabular}

The stages to explore community ideas start from the lower level through the banjar or hamlet deliberations or the "musyawarah dusun". The results of this deliberation are then presented and discussed in the village deliberation or "musyawarah desa".

"We are in the banjar (traditional Balinese hamlet), right? We used to have a deliberation at each banjar. In each banjar the community proposes what they want to plan...then the plans that have been accommodated in the banjar deliberation are brought to the village deliberation" (LO_03)

The exploration of ideas in the health sector was also carried out through village community deliberations or "Musyawarah Masyarakat Desa (MMD)" and the village level stunting deliberations. MMD discusses the results of the Introspective Survey or "Survey Mawas Diri (SMD)". SMD is carried out by integrated health services post (pos pelayanan terpadu/ 
posyandu) cadres by distributing questionnaires made by the public health center to the community representatives chosen as respondents for the survey.

"First we conducted the SMD ... later after we identify the problems found in the village ... will be discussed at the $M M D$ " (LO_06)

“... we ask for cooperation from the cadres to help fill out the SMD form ... we process the data from the survey results to find out the problems existing in the community..." (SA_04)

The village stunting consultative meeting should be carried out in accordance with the direction of the Head of Village. ${ }^{21}$ The Sanding Village Government involved all posyandu cadres during the stunting consultation, while Lodtunduh Village, it only involved representatives of posyandu cadres due to the limited budget. The two villages acknowledged that the village stunting consultative meeting has been able to increase the understanding of the stunting problem.

"... stunting consultative meeting, back then, at first it was only distribution of the honorarium and uniform for the posyandu cadres because they did not understand about stunting yet... in addition, the consultation on stunting was limited because the funds were also limited so that only, one person per posyandu selected as representative..."(LO_03)

“... there are five posyandu cadres in each banjar...this session on stunting consultation has educated them about how to manage and prevent stunting" (SA_02)

\section{Involved actors}

In both villages, the actors involved can be grouped into three groups, namely the village government group, community groups and external party groups. The village government group consists of the village head and village officials including the head of administrative Balinese hamlet or called Kelihan Banjar Dinas. The community group consists of the head of households, Village Consultative Body or the Badan Permusyawaratan Desa (BPD), Village Community Empowerment Body or Lembaga Pemberdayaan Masyarakat Desa (LPM), Community Protection Unit or Perlindungan Masyarakat (LinMas), Village Guard or Bintara Pembina Desa (Babinsa), community leaders from various elements, namely bendesa (community leader in charge of tradition), pekaseh (traditional clerk in charge of village or traditional hamlets' irrigation), youth organization, Women group for Family Empowerment and Welfare organization or Pemberdayaan dan Kesejahteraan Keluarga (PKK), village cadres, teachers. External party groups include health workers (health workers in auxiliary public health centers, public health centers, district health offices) and village assistants (village local assistants and posyandu assistants).

"... those who invited are of course the BPD, regional heads or heads of tradition hamlet, community leaders, youth, PKK, youth organizations, LPM, yes those are the elements we consistently invite, we invite them for the discussion" (SA_01)

"the elements involved first is the chairman of the BPD, LPM, perbekel (traditional name for the head of village), village officials including secretaries, community organizations, Babinsa, village assistants as well ... from community leaders as well, pekaseh, education elements, health elements and various community leaders whom we really need for their ideas and with our BPD members" (LO_04)

\section{Village leadership position}

The exploration of ideas from the community in the hamlet deliberation in Sanding and Lodtunduh Villages has only involved the head of households because they are considered as a figure who is responsible for the problems that occurred in each household. The Kelihan Banjar Dinas as representatives of their residents will convey the aspirations of the residents at the village deliberation meeting. The Kelihan Banjar Dinas is considered as a figure who plays an important role in channeling the aspirations of the community.
"... the ideas proposed by the community are recorded by the clerk or the head of hamlets...then they will be summarized and are taken to the village deliberation meeting" (SA_03)

“... we also receive inputs from various parties, especially heads of hamlet, those who really understand the problem at the grassroot level and often contribute to solve the problem, they are the ones who often go directly to the community" (LO_04)

The proposals that came up in the village deliberation meeting would be accommodated and then ranked by the "team eleven" or the Village Government Work Plan Drafting team (RKPDes). The membership of the "team eleven" has been regulated in a regulation of the Ministry of Home Affairs. ${ }^{22}$ The team eleven in the two villages also involved the village midwives, posyandu cadres and posyandu assistants in compiling details on the costs of stunting prevention activities in the village government working plan (the RKPDes).

"...related to posyandu or stunting prevention, we also involve the midwives, one of the posyandu cadres, as well as posyandu assistants, for example in regard to the provision of infrastructure for prevention activities in the posyandu so that we can calculate the budget" (LO_02)

"...the compilation was done by the cadres and accompanied by the public health centers and the auxillary public health centers, they were given the $R A B$ (the details of the budget plan)" (SA_02)

One of the functions of the BPD is to discuss and agree upon the village regulation draft with the head of village. ${ }^{23}$ The presence of BPD in the planning process in Lodtunduh and Sanding Villages is a sign for redistribution of village government power to the community, because BPD is a representation of the village community.

"... if everyone agrees, the perbekel (traditional name for the head of village) has already signed it with the BPD ..." (LO_03) 


\section{Decision making process}

In the proposals ranking process, the "team eleven" referred to the Village Medium Term Development Plan (RPJMDes) document. If a proposal is in line with the RPJMDes, it will become a priority, and vice versa. The RPJMDes is a village development work plan for one term (6 years) of the head of village which also contains the vision and mission of the village head, the direction of village development policies as well as their activity plans. ${ }^{23}$

"There, you can see in the proposal, the RPJM's scrutiny, whether it is a priority or not. If it is a clear priority, it will be implemented in the APBDes (Village Development Budget)..." (LO_02)

"The consideration for the ranking, yes, we use the RPJMDes" (SA_02)

The draft of the village work plan or the RKPDes that has been completed by the team eleven will be discussed and agreed upon in the village development plan meeting or the musrenbangdes. The RKPDes draft that has been agreed upon will serve as a guide in drafting the Village Regulation on APBDes (Village Development Budget). ${ }^{12}$ The decisionmaking process in the musrenbangdes in the two villages is carried out by consensus agreement between the village government, the BPD and representatives of community elements.

"... decisions are taken jointly in accordance with the priority scale, so it is through deliberation to reach consensus" (LO_01)

"... if there is an agreement, that is what we will put into the APBDes for our annual activities..." (SA_01)

The government of Lodtunduh and Sanding Villages both re-sorted the activities in the RKPDes during the preparation of the APBDes because they need to adjust to the final ceiling of the funds received by the village from the district and the central government. The Lodtunduh and Sanding Village Governments will prioritize the allocation of funds for village administration, village operations and the routine activities first.
The remaining funds are then allocated for other priority activities listed in the RKPDes.

"...we first target the operational cost for the village government, of course, there will be infrastructure development..." (LO_01)

"Later, when an RKP is ready we bring it to the APBDes, that's all you need to do, look for routine activities first...then the village operations are definitely a routine activity..." (SA_02)

The Lodtunduh village has an area of 627 ha with 11 banjar. Meanwhile, Sanding Village has an area of 342 ha and 7 banjar. The Lodtunduh Village Government stated that the large number of banjar caused more aspirations and proposals to emerge, thus more things that needed funding and the more difficult it was to distribute the limited funds. On the other hand, the village government of Sanding feels that its relatively small number of banjar makes it easier to convey aspirations from the community to the village government and makes decision making easier.

"... because we have eleven banjar, of course we should make a priority scale ... we have to divide the funding posts too. Even though we have a large fund, we also need to fund so many things in the village ..." (LO_04)

“... here there is one administrativel village, one traditional village, seven banjar, so it is easy for us to find information ... the decision did not take long ..." (SA_02)

In this study, it was found that there was a change in village midwives in Lodtunduh Village in 2019. The new village midwives seemed to be less likely to take the opportunity to utilize the village funds to manage stunting.

"...2018 I don't know, I am not the village midwife...it's just a suggestion, if it's approved, I'm grateful if not I would team up with the posyandu assistant to buy weighing scales..." (LO_06)

The leadership style of the village head in Sanding tends to be paternalistic, he assumes that the level of knowledge of the community is still very low so that it is impossible to involve the community in the village funds management especially for stunting prevention. In addition, the health sector is considered to be more aware of the problem of stunting than the public.

"...in regard to participation in the sense of taking part in handling it, it is impossible because from a knowledge point of view, their knowledge is very limited. Those who know more about it are from the related agencies, especially from the health office."(SA_01)

The Sanding Village Government is considered as responsive in responding to the input submitted by posyandu cadres and the health sector. The proposal of village midwives and posyandu cadres to procure posyandu equipment had been immediately responded to and budgeted for in the 2019 revised APBDes. Another example is that in the 2020 Sanding Village $A P B D e s$, a budget appeared for innovative youth posyandu activities which were suggested by the public health center's personnel.

"..... in our opinion Sanding is with us...they respond directly...for example, we suggest this...oh yes, just suggest it straight away...the village head is also responsive, in planning too, they said later just submit the proposal..."(SA_04)

The level of understanding and capacity of actors in Sanding and Lodtunduh village were still lacking. The process of identifying community needs and analyzing the problem as the first step in planning to manage stunting is not optimal. The suggestions for stunting prevention that have emerged and have been approved are often of physical infrastructure. In contrast, according to the Lodtunduh village government, the problem faced by the community is often due to poor parenting. Handling of stunting problem in the village has also been focusing only on stunting cases.

"... I don't think it's stunting, it's indeed heredity ... when we handle it, we focus on the individual with stunting" (SA_01)

“... there are many obstacles that we face, especially the awareness of mothers 
to maintain good childcare practice ..." (LO_02)

Proposals for stunting prevention activities in Lodtunduh and Sanding Villages are predominantly coming from posyandu cadres and external parties, namely the health sector (village midwives, staff of public health center) and village assistants.

"Before that, in the planning activities we were accompanied by village assistants... head of the public health center, village midwives...suggestions from active posyandu cadres what we need to do in preventing stunting" (LO_02)

"For stunting, from the auxiliary public health centers, including the mothers in the posyandu who are active ..." (SA_01)

The study found that the fund allocations for stunting prevention activities sourced from the village funds in the APBDes of Lodtunduh and Sanding Villages is more top-down because the village government refers to the central government regulations in governing this matter.

"We refer to the village fund priority law. In the village of Lodtunduh there are also stunting cases, therefore there is a stunting prevention activities in the health sector ...especially in the posyandu health program, "(LO_02)

"... there are already guidelines for it, so we allocate the budget for stunting prevention there ..." (SA_01)

\section{Form of participation}

The form of community participation in Lodtunduh and Sanding Villages is still passive participation. The community attended planning deliberation forums because they received an invitation and not all invited participants could attend.

"When the proposal was made, all banjar communities were invited to provide input ... not all (come) ... there were obstacles such as they have to go to work ..." (SA_03)

"... invited by letter, the one who invite us was the BPD ..." (LO_02)
The communities in Lodtunduh and Sanding Villages appear to be acting more as beneficiaries from the stunting prevention activities that have been budgeted for rather than being an active participant. Governments in both villages assessed the community participation from the attendance in the weighing schedule of children under five at the posyandu. Attendance to the posyandu has been assessed as good by the village government, but this attendance has not been optimal and needs further encouragement from health workers.

"Community participation is usually during posyandu activities...that participation can be seen from the number of attendance..." (SA_02)

"...the posyandu team was also proactive...visited the houses...gave them instructions ..." (LO_06)

The village government is obliged to publish the priority for the use of village funds in public spaces that can be easily accessed by the village community. ${ }^{20}$ Even though the publications and transparency of funds have been in place in both Sanding and Lodtunduh Villages through social media and village information boards, community participation was still appeared to be lacking in monitoring the use of the village funds for stunting prevention. People who actively monitor the use of village funds for stunting activities only come from BPD who supervises the performance of the heads of village.

"BPD...duties as an institution are to supervise the performance of the village heads...one of which is the stunting reduction program is monitored by the BPD" (LO_01)

"Of course, the most active is the BPD member who is the activity supervisor..." (SA_01)

\section{DISCUSSION}

Through this research we found that the village government has carried out the exploration of community ideas starting from the lower level, namely through the banjar deliberations. The various ideas that emerged from the community were then discussed in the village meetings and agreed upon in the musrenbangdes or the village meeting for planning and development. Kelihan Banjar Dinas often considers the heads of household as the figure who is responsible for the problems that occur in each family so it is sufficient to only involve them, whom the majority are male, in the Banjar deliberations. Women's elements such as $P K K$ or the women's group are only involved when there are important events. In addition, health elements such as posyandu cadres are not involved in the banjar deliberations. The lack women's involvement and health elements in this activity causes the exploration of ideas related to maternal and child health problems are often limited and lacking in depth during the banjar deliberations.

Communities in the two villages can only convey their aspirations directly during the banjar deliberations. While at the village meetings and village development planning meetings, the community's aspirations are represented by the Kelihan Banjar Dinas, village opinion leaders and the BPD or village consultative body. The presence of BPD in the budget planning process in Sanding and Lodtunduh Villages showed that redistribution of the village government power to the community was in place, because BPD is a representation of the village community. Nevertheless, BPD needs to increase its function in accommodating and exploring the aspirations of the community, especially those of women's groups as the key elements for women and children's health.

The leadership style found in the two villages tends to be paternalistic. The village government often assumed that the level of community's knowledge is still lacking and the health sector is considered to be more aware of the stunting problem than the community, resulting in the use of village funds for stunting prevention activities predominantly based on inputs from the health sector. In addition, the village government also tends to seek input for planning activities for stunting prevention from village assistants. This is in contradiction from the government regulation which stated that assistance to village communities is based on 
the principles of empowerment and independence to avoid dependency. ${ }^{10}$ The village government should avoid this dependency and empower the community more in the planning process for stunting prevention activities rather than seeking outside view. The village government should also allocate more funds for stunting deliberations and meetings so that it can involve more participants from various elements which in turn will increase the understanding of the village community about the stunting problems and applicable solutions for their community.

Village territorial factors were also found to affect the utilization of village funds for stunting prevention. Lodtunduh Village has a larger area than Sanding Village. The number of banjar in Lodtunduh Village is also almost double that of Sanding Village. This large number of banjar is recognized by the village government, causing the more aspirations and proposals to emerge, thus more things that need funding and the more difficult it is to divide funding allocations.

The level of understanding and capacity of actors on stunting prevention programs is still lacking in the utilization of village funds for stunting prevention. The definition and risk factors for stunting are not well understood by these actors. The process of identifying community needs and analyzing the problem as a first step in planning to overcome stunting problem has not been carried out optimally. The suggestions for stunting prevention program that emerged and approved were more physical in nature which could easily be seen, such as the provision of posyandu facilities. However, the paradox was the village government admits the problems related to stunting faced by the community are more non-physical in nature, namely poor parenting styles and unequal public knowledge about stunting prevention. Therefore, this problem should be prioritized by the village government in the village funds allocation for stunting. The village government itself realizes that it still needs to increase information dissemination about stunting prevention to the community, improve coordination with traditional institutions and youth organizations, and educate the community that the problem of stunting is not only the responsibility of the village government but requires participation from the whole community, yet they did not allocate sufficient resources for these activities.

\section{Study Limitations}

The study had some limitations to bear in mind for generalization of its results. First is that the number of informants was not the same between the two villages where more informants came from Lodtunduh Village compared to Sanding Village. The difference in the number of informants between the two villages caused the completeness of the information obtained was not the same as one another.

\section{CONCLUSION}

The level of community participation in the utilization of village funds for stunting prevention in both villages of stunting loci chosen for the case study was still at the pseudo participation level of Placation, despite the difference in the percentage of village fund allocation for health. The majority of proposals or recommendation for stunting prevention program came from posyandu cadres, health care workers and the village assistants. Final decision making in the planning stage was largely depending on the village government. The budgeted stunting prevention activities were mostly for specific nutrition interventions. The community role was more as beneficiaries rather that active participants in the program. Village territorial factors, paternalistic leadership styles, lack of understanding and lack of capacity of key figures were some challenges in the utilization of village funds for stunting prevention in the stunting loci in Gianyar District. The village government should further empower village communities by opening discussion forums related to stunting prevention which also should involve more women. The village government should also empower related village institutions.

\section{ACKNOWLEDGEMENTS}

The author would like to thank the Head of Lodtunduh and Sanding Villages who gave their permission and assistance for the data collection. The researcher also would like to thank all informants for their valuable contributions and willingness to participate in the study.

\section{AUTHOR CONTRIBUTIONS}

MADP designed and conducted the study, analyzed the data, wrote the first draft of the manuscript and edited the manuscript. DSL and NKS were involved in the study design and the research concept, provided feedback and edited the manuscript.

\section{CONFLICT OF INTEREST}

The author declares no conflict of interest.

\section{FUNDING}

This research is personally funded by the researchers.

\section{REFERENCES}

1. Unicef/WHO/World Bank Group. Levels and trends in child malnutrition: key findings of the 2019 edition of the joint child malnutrition estimates. Geneva: World Health Organization; 2019.

2. Ministry of National Development Planning of Indonesia. Kebijakan percepatan penurunan stunting [Stunting reduction acceleration policy]. Presented in The Training of Trainers Candidates for Capacity Buiding Modules in Convergen Action to Accelerate Stuntung Reduction in Districts/Cities, Jakarta, $10^{\text {th }}$ March, 2020.

3. Stein $A D$, Wang M, Martorell R, Norris SA, Adair LS, Bas I, et al. Growth patterns in early childhood and final attained stature: data from five birth cohorts from low- and middle-income countries. Am J Hum Biol. 2010; 22(3): 353-359.

4. Walker SP, Chang SM, Powell CA, Simonoff E, Grantham-mcgregor SM. Early childhood stunting is associated with poor psychological functioning in late adolescence and effects are reduced by psychosocial stimulation. The Journal of Nutrition. 2007; 137(11): 2464-2469.

5. Woldehanna T, Behrman JR, Araya MW. The effect of early childhood stunting on children's cognitive achievements: evidence from young lives Ethiopia. Ethiopian Journal of Health Development. 2017; 31(2): 75-84.

6. Hoffman DJ, Sawaya AL, Verreschi I, Tucker KL, Roberts SB. Why are nutritionally stunted children at increased risk of obesity? Studies of metabolic rate and fat oxidation in shantytown children from Sao Paulo, Brazil. The American Journal of Clinical Nutrition. 2000; 72(3): 702707.

7. McGovern ME, Krishna A, Aguayo VM, Subramanian SV. A review of the evidence linking child stunting to economic outcomes. International Journal of Epidemiology. 2017; 46(4): 1171-1191. 
8. Renyoet BS, Martianto D, Sukandar D. Potensi kerugian ekonomi karena stunting pada balita di Indonesia tahun 2013 [Economic potential losses due to stunting in under five years old children in Indonesia year 2013]. J Gizi dan Pangan. 2016; 11(3): 247-254.

9. Satriawan E. Strategi Nasional Percepatan Pencegahan Stunting Periode 2018-2024 [National strategy for accelerating stunting prevention 2018-2024]. National Team for the Acceleration of Poverty Reduction (TNP2K) Secretariat of the Vice President of the Republic of Indonesia. 2018.

10. Ministry of Health of Indonesia. Keputusan Menteri Kesehatan Republik Indonesia Nomor HK.02.02/MENKES/52/2015 tentang Rencana Strategis Kementerian Kesehatan Tahun 20152019 [Decree of The Ministry of Health of Indonesia No. HK.02.02/MENKES/52/2015 on the Ministry of Health Strategic Plan for 20152019]. Jakarta: Ministry of Health of Indonesia; 2015.

11. Gianyar District Health Office. Persentase dana desa untuk Usaha Kesehatan Bersumberdaya Masyarakat (UKBM) Kabupaten Gianyar tahun 2018 dan 2019 [Percentage of village funds for Community Based Health Enterprises (UKBM) of Gianyar District in 2018 and 2019]. Gianyar: Gianyar District Health Office; 2019

12. Ministry of Village, Disadvantaged Regions and Transmigration of Indonesia. Peraturan Menteri Desa, Pembangunan Daerah Tertinggal, dan Transmigrasi Republik Indonesia Nomor 16 Tahun 2018 tentang prioritas penggunaan dana desa tahun 2019 [Regulation of The Minister of Village, Disadvantaged Regions and Transmigration of Indonesia No. 162018 on village funds usage priority for 2019]. Jakarta: Ministry of Village, Disadvantaged Regions and Transmigration of Indonesia; 2018.

13. Ministry of Village, Disadvantaged Regions and Transmigration of Indonesia. Peraturan Menteri
Desa, Pembangunan Daerah Tertinggal, dan Transmigrasi Republik Indonesia Nomor 11 Tahun 2019 tentang prioritas penggunaan dana desa tahun 2020 [Regulation of The Minister of Village, Disadvantaged Regions and Transmigration of Indonesia No. 112019 on village funds usage priority for 2020]. Jakarta: Ministry of Village, Disadvantaged Regions and Transmigration of Indonesia; 2019.

14. World Health Organization. Community participation in local health and sustainable development: approaches and techniques. Regional Office for Europe: World Health Organization; 2002

15. Tumbel SM. Partisipasi masyarakat dalam pengelolaan dana Desa Tumaluntung Satu, Kecamatan Tareran, Kabupaten Minahasa Selatan [Community participation in the management of funds in Tumaluntung Satu Village, Tareran Sub-District, South Minahasa District]. Politico: Jurnal Ilmu Politik. 2017; 6(1): 161029.

16. Luthfi A, Rini HS, Aji F, Arsal T, Rochana T. Partisipasi masyarakat dalam pengelolaan dan pemanfaatan dana desa di Desa Keji Kabupaten Semarang [Community participation in the management and utilization of village funds in Keji Village, Semarang District]. Matra Pembaruan: Jurnal Inovasi Kebijakan. 2017; 1(2): 121-130.

17. Hulu Y, Harahap RH, Nasution MA. Pengelolaan dana desa dalam pemberdayaan masyarakat [Village fund management in community empowerment]. Jurnal Pendidikan Ilmu-Ilmu Sosial. 2018; 10(1): 146-154.

18. Suarsih S, Sunjaya DK, Setiawati EP, Wiwaha G, Herawati DM, Rinawan F. Analisis kebijakan dana desa untuk pembangunan kesehatan di Kabupaten Malinau dengan pendekatan segitiga kebijakan [Policy analysis of village funds for health development in Malinau
District by triangle policy approach]. Jurnal Sistem Kesehatan. 2017; 2(4): 211-217.

19. Arnstein SR. A ladder of citizen participation. Journal of the American Institute of Planners. 1969; 35(4): 216-246.

20. Carpentier N. Beyond the ladder of participation: an analytical toolkit for the critical analysis of participatory media processes. Javnost-The Public. 2016; 23(1): 7088.

21. National Team for the Acceleration of Poverty Reduction (TNP2K). Panduan konvergensi program/kegiatan percepatan pencegahan stunting [Guidelines for the convergence of stunting prevention programs/activities]. 2018th ed. National Team for the Acceleration of Poverty Reduction (TNP2K) Secretariat of the Vice President of the Republic of Indonesia, editor. 2018.

22. Ministry of Home Affairs of Indonesia. Peraturan Menteri Dalam Negeri Republik Indonesia Nomor 114 Tahun 2014 tentang Pedoman Pembangunan Desa [Regulation of The Minister of Home Affairs of Indonesia No. 114 Year 2014 on Village Development]. Jakarta: Ministry of Home Affairs of Indonesia; 2014.

23. Ministry of Home Affairs of Indonesia. Peraturan Menteri Dalam Negeri Republik Indonesia Nomor 110 Tahun 2016 tentang Badan Permusyawaratan Desa [Regulation of The Minister of Home Affairs of Indonesia No. 1102016 on Village Council]. Jakarta: Ministry of Home Affairs of Indonesia; 2017.

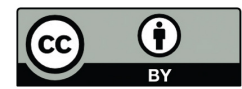

This work is licensed under a Creative Commons Attribution 